\title{
Does Age Affect the Size of Metastatic Lymph Nodes in Head and Neck Cancer?
}

\author{
Nilda SUSLU ${ }^{1}$, A. Sefik HOSAL ${ }^{1}$, Yesim G.G. TEZEL ${ }^{2}$, Bulent SOZERI ${ }^{1}$, \\ Ibrahim GULLU ${ }^{3}$, Anıl DOLGUN ${ }^{4}$ \\ 1 Hacettepe University, Faculty of Medicine, Department of Otorhinolaryngology \\ ${ }^{2}$ Hacettepe University, Faculty of Medicine, Department of Pathology \\ ${ }^{3}$ Hacettepe University, Faculty of Medicine, Department of Medical Oncology \\ ${ }^{4}$ Hacettepe University, Faculty of Medicine, Department of Bioistatistics, Ankara, TURKEY
}

\begin{abstract}
The aim of the study was to determine if age plays a role in the size of metastatic lymph nodes in elderly patients with squamous cell carcinoma of the head and neck (HNSCC). In 180 HNSCC patients with metastatic lymph nodes, largest metastatic lymph node $(S M L N)$, diameter of metastatic deposit (DMD), and the ratio of non-metastatic lymphoid tissue to the size of largest metastatic lymph node (RNML) were recorded. The patients were divided into 2 groups (group 1: <65 years; group 2: $\geq 65$ years) to analyse the correlation between SMLN, DMD, RNML, and age. ,Median SMLN and DMD in the entire study population was $17 \mathrm{~mm}$ and $15 \mathrm{~mm}$, respectively. There was not a significant correlation between age, and SMLN or DMD $(r=0.039$ and $P=0.64$, and $r=0.055$ and $P=$ 0.54, respectively). Extracapsular spread (ECS) was observed in $57.6 \%$ of patients in group 2 and in $50.4 \%$ of patients in group 1. Although ECS was more frequent in group 2, there was not a significant difference in SMLN, RMLN and DMD between the 2 groups $(P>0.05)$. In conclusion, age did not affect the size of metastatic lymph nodes in the patients with HNSCC.
\end{abstract}

Keywords: Head and neck neoplasms, Squamous cell carcinoma, Lymph node, Metastases, Aging, Immunity

\section{ÖZET}

Baş Boyun Kanserlerinde, Yaş Metastatik Lenf Nodu Büyüklüğünü Etkiliyor mu?

Bu çalş̧manın amacı, baş boyun skuamöz hücreli kanserinde, ileri yaşın metastatik lenf nodu büyüklüğü üzerinde etkisi olup olmadığını araştırmaktır. 180 baş boyun kanserli ve metastatik lenf nodu tespit edilen hastalarda, en büyük metastatik lenf nodunun çapı (BLN), lenf nodu içerisinde metastatik tümör odağının çapı (TO) ve tümör tarafından tutulmamış kısmın tüm lenf noduna hacim yüzdesi (NAY) hesaplanmıştır. Hastalar 65 yaş altı (grup 1) ve üstü (grup 2) olmak üzere iki gruba ayrımıştır. Bu iki grup incelenerek, yaş ile BLN, TO ve NAY değerleri arasında korelasyon olup olmadığı analiz edilmiştir. Tüm çalışma grubunda, BLN ve TO değerleri sırasıyla $17 \mathrm{~mm}$ and $15 \mathrm{~mm}$ idi. Yaş ile BLN ve TO arasında istatistiksel olarak anlamlı fark bulunmadı $(r=0.039, P=0.64$, ve $r=0.055$ and $P=0.54$, sırasılya). Ekstrakapsüler yaylım (EKY), grup 1'deki hastaların \%50.4'ünde; grup 2'deki hastaların \%57.6'sında tespit edildi. EKY, grup 2'deki hastalarda daha sıklıkla gözlenmesine rağmen, her iki grup arasında BLN, TO ve NAY açısından her iki grup arasında istatistiksel olarak anlamlı fark bulunmamıştır ( $P>0.05)$. Sonuç olarak, Baş boyun kanserli hastalarda, yaşın metastatik lenf nodu büyüklüğünü etkilemediği ortaya konmuştur.

Anahtar Kelimeler: Baş boyun kanseri, Skuamöz hücreli kanser, Lenf nodu, Metastaz, Yaş, İmmünite 


\section{INTRODUCTION}

Squamous cell carcinoma of the head and neck (HNSCC) most commonly occurs in males aged $>40$ years with a history of heavy alcohol use coupled with smoking. Cervical lymphatics play an active role in the biological behavior of HNSCC. Cells from the primary cancer enter the multi-level, anastomosing network of the lymphatics that drain via a series of lymph nodes. ${ }^{1}$ Metastatic lymph node involvement in the neck is dependent on the size of the primary tumor, increasing with $\mathrm{T}$ stage. ${ }^{2}$ Unfortunately, the proliferation of cancer within the nodes often leads to uncontrolled regional disease and mortality. Cancer in the cervical lymph nodes reduces the chances of a patient's curability by $50 \%$ and is responsible for $50 \%-95 \%$ of recurrent disease. ${ }^{3}$ Cancer in the cervical nodes, whether or not clinically apparent, inevitably results in unacceptable rates of morbidity and mortality; therefore, assessment and treatment of regional lymph nodes in the neck are of utmost importance in the management of patients with HNSCC.

It is well known that tumors may invoke immune responses that vary widely by tumor type. The microenvironment of a developing tumor is infiltrated by numerous host cells, such as inflammatory cells, endothelial cells, and fibroblasts. Recent data suggest that both innate and adaptive arms of the immune system are involved in tumor prevention. ${ }^{4}$ The progressive decline in immune function (immunosenescence) that develops with age seems to play a fundamental role in the observed increase in the incidence of cancer in the elderly. ${ }^{5}$

In cases of cancer, regional lymph node cells are among the first components of the immune system to have contact with tumor cells or their products. HNSCC often contains large mononuclear cell infiltrates in regional lymph nodes that are composed primarily of T-cells, which might be indicative of an in situ immune reaction against the malignant HNSCC cells. ${ }^{6}$ Extensive lymphocytic infiltration has been associated with a favorable prognosis in patients with HNSCC. ${ }^{7}$ As metastasis to regional lymph nodes constitutes the main route of progression and dissemination of HNSCC in humans, immune response of the lymphoid nodes is critical for control of the disease. Several types of immune system dysfunction in the elderly might be related to irregularities of apoptotic processes and a decreased response of lymphoid cells to the proliferative and activating signals. ${ }^{8}$ The most important phenomena characteristic of the aging process are a certain loss of cellular proliferative capacity, and involution of tissues and organs. The size of metastatic lymph nodes in the elderly are expected to be smaller than in non-elderly individuals due to the decrease in nodal reactions associated with the anti-tumor response. The aim of the present study was to determine if there is an association between the size of metastatic lymph nodes and age in patients with HNSCC.

\section{PATIENTS AND METHODS}

We retrospectively reviewed the records of patients with head and neck carcinomas that were treated at Hacettepe University, School of Medicine, Department of Otorhinolaryngology, Head and Neck Surgery between 1980 and 2011. In all, 180 patients from our database that underwent neck dissection and had histopathological evidence of cervical lymph node metastasis were included in the study. Patients with histological subtypes other than squamous cell carcinoma and a history of preoperative radiotherapy were excluded. Tumors were staged according to the American Joint Committee of Head and Neck Carcinomas 2002 TNM staging system. ${ }^{9}$ Individual demographic and clinicopathological data were collected, including tumor size, nodal stage, neck dissection type, and extracapsular invasion. Histopathological assessment of each neck dissection specimen was re-examined by an expert pathologist. The size of each patient's largest metastatic lymph node (SMLN) and the profile diameter of metastatic deposit (DMD) were recorded.

The correlation between age, and SMLN and DMD in the entire study population was analyzed using Pearson's correlation analysis. The cut-off point for age was determined to be 65 years, and SMLN and DMD in group 1 (aged $<65$ years) was compared to those in group 2 (aged $\geq 65$ years). Additionally, the ratio of non-metastatic lymphoid tissue to the size of largest metastatic lymph node (RNML) was analyzed. All statistical analyses were performed using SPSS v.16.0 (SPSS Inc., Chicago, IL). Statistical significance was set at $\mathrm{p}<0.05$. 


\section{RESULTS}

In all, 180 patients in our database met the study's inclusion criteria. Among the 180 patients, 150 $(83.3 \%)$ were male and $30(16.7 \%)$ were female. Mean age at diagnosis was 55 years (range: 23-90 years). $\mathrm{N}$-status was determined via clinical examination and computed tomography (CT), and/or magnetic resonance imaging (MRI). Baseline demographic and tumor data, including carcinoma localization, clinical tumor size and nodal stage, differentiation of tumor, neck dissection type, mode of treatment, and extracapsular spread, are shown in Table 1.

Median SMLN in the entire study population was $17 \mathrm{~mm} \pm 9 \mathrm{~mm}$ (range: $3 \mathrm{~mm}-50 \mathrm{~mm}$ ) and there was not a significant correlation between SMLN and age $(\mathrm{r}=0.039, \mathrm{p}=0.64)$. Mean SMLN in group 1 was $18.8 \mathrm{~mm} \pm 8.2 \mathrm{~mm}$, versus $19.3 \mathrm{~mm} \pm 11.5$ $\mathrm{mm}$ in group 2. Based on the independent samples test, there was not a significant difference in SMLN between the 2 groups ( $\mathrm{p}=0.838$ ).

Median DMD in the entire study population was 15 $\mathrm{mm} \pm 11.2 \mathrm{~mm}$ (range: $0.2 \mathrm{~mm}-50 \mathrm{~mm}$ ) and there was not a significant correlation between DMD and age $(\mathrm{r}=0.055, \mathrm{p}=0.54)$. Mean DMD in group 1 was $15.1 \mathrm{~mm} \pm 10.3 \mathrm{~mm}$, versus $16.9 \mathrm{~mm} \pm 14.3$ $\mathrm{mm}$ in group 2 . There was not a significant difference in DMD between the 2 groups ( $\mathrm{p}=0.538$ ).

RNML (SMLN - DMD/SMLN ¥ $100=$ RNML) decreased with age, but not significantly ( $\mathrm{r}=-0.12$, $\mathrm{P}=0.889$ ). Mean RNML was $26.9 \%$ in group 1 and $24 \%$ in group 2, but the difference was not significant $(\mathrm{p}=0.697)$ (Table 2). Extracapsular spread (ECS) was observed in $19(57.6 \%)$ patients in group 2 and in $61(50.4 \%)$ patients in group 1. Although the frequency of ECS was higher in group 2, the difference between the 2 groups was not significant $(\mathrm{p}>0.05)$.

\section{DISCUSSION}

Most head and neck cancers are squamous cell cancers of the upper aerodigestive tract (HNSCC), which is more common in males and patients aged $>50$ years. Tumor cells disseminate via direct invasion into surrounding tissues and spread to body cavities. Dissemination can also occur via invasion of tumors cells into the blood supply (hematogenous

\begin{tabular}{|c|c|c|}
\hline & $\mathbf{n}$ & $\%$ \\
\hline \multicolumn{3}{|l|}{ Carcinoma localization } \\
\hline Larynx & 100 & 55.6 \\
\hline Hypopharynx & 4 & 2.2 \\
\hline Oral cavity & 60 & 33.4 \\
\hline Oropharynx & 8 & 3.3 \\
\hline Other & 8 & 3.3 \\
\hline \multicolumn{3}{|l|}{ Differentiation } \\
\hline Non-differentiated & 8 & 6.1 \\
\hline Poor & 20 & 15.2 \\
\hline Moderate & 58 & 43.9 \\
\hline Well & 42 & 31.8 \\
\hline Basaloid type & 4 & 3 \\
\hline \multicolumn{3}{|l|}{ Clinical tumor stage } \\
\hline $\mathrm{T} 1$ & 18 & 10.2 \\
\hline $\mathrm{T} 2$ & 76 & 43.2 \\
\hline Т3 & 44 & 25 \\
\hline $\mathrm{T} 4$ & 38 & 21.6 \\
\hline \multicolumn{3}{|l|}{ Clinical nodal stage } \\
\hline NO & 75 & 41.9 \\
\hline $\mathrm{N} 1$ & 39 & 34.6 \\
\hline $\mathrm{N} 2 \mathrm{a}$ & 15 & 8.4 \\
\hline $\mathrm{N} 2 \mathrm{~b}$ & 8 & 4.4 \\
\hline $\mathrm{N} 2 \mathrm{c}$ & 10 & 5.6 \\
\hline N3 & 9 & 5 \\
\hline \multicolumn{3}{|l|}{ Treatment } \\
\hline Surgery & 48 & 27 \\
\hline Surgery + radiotherapy & 58 & 33 \\
\hline Surgery + chemoradiotherapy & 48 & 27 \\
\hline Surgery + palliative chemoradiotherapy & 7 & 4 \\
\hline Preoperative chemoradiotherapy & 16 & 9 \\
\hline \multicolumn{3}{|l|}{ Neck dissection } \\
\hline Selective & 55 & 30.6 \\
\hline Modified radical & 31 & 17.2 \\
\hline Radical & 94 & 52.2 \\
\hline \multicolumn{3}{|l|}{ Extracapsular spread } \\
\hline Present & 80 & 51.6 \\
\hline Absent & 75 & 48.4 \\
\hline
\end{tabular}




\begin{tabular}{|c|c|c|c|c|}
\hline & Age (years) & $n$ & Mean \pm SD $(\mathrm{mm})$ & $\begin{array}{l}\text { Independent Samples Test } \\
\text { P value }\end{array}$ \\
\hline \multirow[t]{2}{*}{ SMLN } & $<65$ & 117 & $18.8 \pm 8.3$ & 0.838 \\
\hline & $\geq 65$ & 32 & $19.3 \pm 11.5$ & \\
\hline \multirow[t]{2}{*}{ DMD } & $<65$ & 101 & $15.1 \pm 10.3$ & 0.538 \\
\hline & $\geq 65$ & 26 & $16.9 \pm 14.3$ & \\
\hline \multirow[t]{3}{*}{ RNML } & & & Mean \pm SD (\%) & \\
\hline & $<65$ & 101 & $26.9 \pm 33$ & 0.697 \\
\hline & $\geq 65$ & 26 & $24 \pm 36$ & \\
\hline
\end{tabular}

metastasis) and lymphatic system (lymphatic metastasis). Clinical and pathological observations suggest that transport of tumors cells via the lymphatics is the most common route of initial dissemination of HNSCC, and the cancerous cells generally spread following natural drainage routes.

In the human body there are approximately 800 lymph nodes, of which roughly 300 are located in the head and neck region..$^{10}$ Metastatic lymph node involvement in the neck is dependent on the size of the primary tumor, increasing with $\mathrm{T}$ stage 3 . Distant metastatic disease often occurs quite late in patients with HNSCC, despite the presence of involved cervical neck nodes, which suggests that the filtration function of the cervical lymphatics is effective. Lymph node metastasis is one of the earliest features of tumor cell dissemination in HNSCC. The impact of nodal metastasis on survival has been known for many years and is reported to reduce disease-specific survival (DSS) by 50\%." The importance of nodal metastasis to prognosis forms the basis of TNM staging. This process is critical for determining prognosis and planning therapeutic strategies. Apart from the presence or absence of lymph node metastases, the size, number and level of the methastatic lymph nodes are considered by most researchers to affect prognosis. ${ }^{12}$ As such, management of the neck remains the cornerstone of the management of head and neck cancer.

It is well known that many tumors are antigenic for hosts that invoke immune responses. A developing tumor is usually infiltrated by numerous inflamma- tory cells. ${ }^{5}$ Dysregulation of immune system function in older people ( $\geq 65$ years), involves both the reaction against infectious pathogens and anti-tumor defense, which leads to a decrease in activity in both circumstances. As many mechanisms involved in the ageing process share molecular pathways implicated in carcinogenesis, the existence of a relationship between age and the risk of tumor development is probable. ${ }^{13}$ One risk in particular is impaired apoptosis. Zhou et $\mathrm{al}^{14}$, reported the immunosuppressive role of some cytokines, such as IL-10 and TGF- $B$, which increasing with ageing tend to suppress the cell-mediated activity, needed to control tumor growth and to destroy tumor cells. Another pro-inflammatory cytokine over-expressed in the elderly is IL-6, which influences TGF- $\beta$-mediated tumorigenesis via increasing the number of TGF- $\beta$ receptors.

Lymph nodes are vital immunologic organs. They are traditionally regarded as having 3 compartments, the cortex, paracortex, and medulla. ${ }^{8} \mathrm{~B}-$ and T-cells home to separate areas within these compartments, interact with antigen-presenting cells and undergo clonal expansion. Inside lymph nodes antigen-presenting cells and naïve lymphocytes come together to initiate primary immune responses..$^{15}$ Antigen-presenting cells display antigens to lymphocytes, reactive lymphocytes undergo clonal expansion to produce new lymphocytes and plasma cells, and the resulting plasma cells secrete antibodies into the lymph. These immunological processes occur in the reticular meshwork- a specialized 
stromal structure that supports, guides, and organizes interactions between lymphocytes and antigenpresenting cells. ${ }^{16,17}$ Particulate antigens are also filtered out of the lymph and destroyed by macrophages. Lymph node deep cortex has been shown to be a thymus-dependent region populated primarily by T-lymphocytes. This region expands and exhibits proliferation of large lymphoid cells during the early stage of immune response against thymus-dependent antigens and experimental tumors. Germinal centers were reported to be thymus-independent regions associated with the production of plasma cells and humoral immune response. ${ }^{8}$

Immunosenescence is defined as a state of dysregulated immune function that contributes to an increase in susceptibility to infection, cancer, and autoimmune diseases in aged organisms, including humans. ${ }^{18}$ The progressive decline of the immune system (immunosenescence), including cellular and molecular alterations, affects both innate and adaptive immunity. ${ }^{19}$ The strongest evidence of direct tumor reactivity by cellular immune mechanisms in HNSCC is derived from analysis of reactions in regional lymph nodes and of lymphocyte infiltration in the tumor itself..$^{20,21}$ Early studies indicated that HNSSC patients with lymph nodes stimulated by tumors have a better prognosis. ${ }^{22,23}$ Analysis of the lymphocytes in uninvolved and involved lymph nodes indicates that in both cases the majority are Tlymphocytes.$^{24}$ Patients with HNSCC have cell-mediated immune defects and anergy, and the existence of these immunological defects has been well established, which progress with disease. ${ }^{25-27}$ In contrast to the clearly documented immunosuppression in systemic cell-mediated responses 28,29 , recent studies reported that the number of T-lymphocytes in uninvolved and metastatic neck lymph nodes are comparable to that observed in controls.30,31 Furthermore, mitogen-induced proliferative responses of T-cells in cancer nodes were reported to be normal. ${ }^{32}$

With aging, the thymus involutes and the supply of naïve T-cells gradually decreases. ${ }^{25}$ Although the Tcell immune response is affected most dramatically by aging, age-associated immunologic changes also occur in the phenotype and function of natural killer cells. ${ }^{26} \mathrm{NK}$-cells are characterized by their ability to kill cancer cells and virally infected cells without prior sensitization..$^{27,28}$ Aging influences the quantitative levels of NK-cells by increasing their absolute number, and decreasing both endogenous and lymphokine-induced lytic activity. ${ }^{29}$

To the best of our knowledge the present study is the first to report an association between immunosenescence and size of the largest metastatic lymph node. In the light of the present findings, size of the largest metastatic lymph node in the elderly can be expected to be smaller than in younger patients due to a decrease in cellular proliferation and nodal reactions for anti-tumor response. Pearson's correlation analysis in the present study showed that there wasn't a significant decrease in the size of metastatic lymph nodes with age. Additionally, there wasn't a significant difference in the size of the largest metastatic lymph node dissected during surgery between group 1 and group 2 .

Changes that lead to lymph node hyperplasia in cancer patients are not necessarily accompanied by the presence of tumor cells. These changes may be induced by the interaction between immune cells and products secreted by different cell types. ${ }^{8,14}$ To determine if there is a change in the size of non-involved lymphoid tissue (containing only host immune cells, no tumor cells) we calculated the ratio of uninvolved tissue to that of the entire node. A decrease in the ratio was observed with age, but the difference was not significant. Although HNSCC itself may play a role in decreases immune responses, we think that it will affect both elderly and younger patients; however, as the present findings were not based on immunological assay, they do not provide evidence that there was a decrease in the immune cell population or proliferation in involved lymph nodes in group 2, as compared to group 1 .

\section{CONCLUSION}

This is the first study to investigate the role of age in the size of metastatic lymph nodes. Previous immunologic studies have shown that a progressive decrease in immunity in the elderly may play a role in the immune response of regional lymph nodes. The present findings indicate that these changes did not affect the size of involved lymph nodes, which is an important criterion when planning adjuvant therapy following neck surgery. 


\section{REFERENCES}

1. Gregoire V, Lee N. Radiation therapy and management of the cervical lymph nodes and malignant skull base tumors. In: Flint PW et al, editors. CummingsOtolaryngology Head and Neck Surgery. 5th ed. Philedelphia, Mosby Inc, 2010: 1682-1701.

2. Bataini JP, Bernier J, Brugere J, et al. Natural history of neck disease in patients with squamous cell carcinoma of the oropharynx and pharyngolarynx. Radiother Oncol 3: 245-255, 1985.

3. Mamelle G, Pampurik J, Luboinski B, et al. Lymph node prognostic factors in head and neck squamous cell carcinomas. Am J Surg 168: 494-498, 1994.

4. Malaguarnera L, Di Mauro S, Imbesi RM, et al. Immunosenescence and cancer: a review. Arch Gerontol Geriatr 32: 77-93, 2001.

5. Murasko DM, Nelson BJ, Silver R, et al. Immunologic response in an elderly population with a mean age of 85. Am J Med 81: 612-618, 1986.

6. Yasumura S, Hirabayashi H, Schwartz DR, et al. Human cytotoxic T-cell lines with re-stricted specificity for squamous cell carcinoma of the head and neck. Cancer Res 53: 1461-1468, 1993.

7. Hiratsuka H, Imamura M, Ishii $Y$, et al. Immunohistologic detection of lymphocyte subpopulations infiltrating in human oral cancer with special reference to its clinical significance. Cancer 53: 2456-2466, 1984.

8. Willard-Mack CL. Normal Structure, Function, and Histology of Lymph Nodes Toxicol Pathol 34: 409424, 2006.

9. American Joint Committee on Cancer. Part II. Head and Neck. Pharynx. Larynx. In: Greene FL, editor. AJCC cancer staging manual. 6th. ed. New York, Springer, 2002: 33-57.

10. Van Trappen PO, Pepper MS. Lymphatic dissemination of tumour cells and the formation of micrometastases. Lancet Oncology 3: 44-52, 2002.

11. Shah JP. Patterns of cervical lymph node metastasis from squamous carcinomas of the upper aerodigestive tract. Am J Surg 160: 405-409, 1990.

12. Peters LJ, Goepfert H, Ang KK, et al. Evaluation of the dose for postoperative radiation therapy of head and neck cancer: first report of a prospective randomized trial. Int J Radiat Oncol Biol Phys 26: 3-11, 1993.

13. Irmiger-Finger I. Science of cancer and aging. J Clin Oncol 25: 1844-1851, 2007.

14. Zhou D, Chrest FJ, Adler W, et al. Increased production of TGF-beta and IL-6 by aged spleen cells. Immunol Lett 36: 7-11, 1993.

15. Kaldjian EP, Gretz JE, Anderson AO, et al. Spatial and molecular organization of lymph node $T$ cell cortex: a labyrinthine cavity bounded by an epithelium-like monolayer of fibroblastic reticular cells anchored to basement membrane-like extracellular matrix. Int Immunol 13: 1243-1253, 2001.
16. Gretz JE, Kaldjian EP, Anderson AO, Shaw S. Sophisticated strategies for information encounter in the lymph node: the reticular network as a conduit of soluble information and a highway for cell traffic. J Immunol 157: 495-459, 1996.

17. Gretz JE, Anderson AO, Shaw S. Cords, channels, corridors and conduits: critical architectural elements facilitating cell interactions in the lymph node cortex. Immunol Rev 156: 11-24, 1997.

18. Pawelec G, Solana R. Immunosenescence. Immunol Today 18: 514-516, 1997.

19. Malaguarnera L, Cristaldi E, Malaguarnera M. The role of immunity in elderly cancer. Critic Rev Oncol Hematol 74: 40-60, 2010.

20. Hadden JW. The immunology of head and neck cancer: prospects for immunotherapy. Clin Immunother (now biodrugs) 3: 362-385, 1995.

21. Vitolo D, Letessier EM, Johnson JT, et al. Immunologic effector cells in head and neck cancer. J Natl Cancer Inst Monogr 12: 203-8, 1992.

22. Berlinger NT, Tsakraklides J, Pollack K, et al. Immunology assessment of regionale lymph node histology in relation to survival in head and neck carcinoma. Cancer 37: 697-705, 1976.

23. Patt BS, Close LG, Vuitch F. Prognostic significance of sinus histiocytosis in methastatic laryngeal cancer. Laryngoscope 103: 498-502, 1993.

24. Hadden JW. The immunopharmacology of head and neck cancer: an update. Int J Immunopharmac 19: 629-644, 1997.

25. Katz AE. Advances in the immunology of head and neck cancer. Otolaryngol Clin N Am 13: 431-36, 1980.

26. Newbill ET, Johns ME. Immunology of head and neck cancers. CRC Crit Rev Clin Lab Sci 19: 1-25, 1983.

27. Lichtenstein A, Zighelboim J, Dorey F, et al. Comparison of immune derangements in patients with different malignancies. Cancer (Phila.) 45: 2090-2095, 1980.

28. Hayashi $\mathrm{Y}$, NishidaT, Yoshida $\mathrm{H}$, et al. Peripheral $\mathrm{K}$ lymphocyte population in head and neck cancer. Cancer (Phila.) 53: 2507-2514, 1984.

29. Schantz SP, Poisson L. Natural killer cell response to regional lymph node metastases. Arch Otolaryngol Head Neck Surg 112: 545-551, 1986.

30. Saxon A, Portis J. Lymphoid subpopulation changes in regional lymph nodes in squamous head and neck cancer. Cancer Res 37: 1154- 58, 1977.

31. Roubin R, Bekkoucha F, Fondaneche MC, et al. Lymphoid cells in lymph nodes and peripheral blood of patients with squamous cell carcinoma of the head and neck. J Cancer Res Clin Oncol 102: 277- 87, 1982.

32. Saxon A, Portaro J. Preservation of in vitro biological functions in regional lymph node lymphocytes in squamous head and neck cancer. Cancer Res 37: 115964, 1977. 
33. Hakim FT, Flomerfelt FA, Boyiadzis M, Gres RE. Aging, immunity and cancer. Curr Opin Immunol 16: 151-6, 2004.

34. Mocchegiani E, Malavolta M. NK and NKT cell functions in immunosenescence. Aging Cell 3: 177-184, 2004.

35. Robertson MJ, Ritz J. Biology and clinical relevance of human natural killer cells. Blood 76: 2421-2438, 1990.

36. Almeida-Oliveira A, Diamond HR. Antileukemic activity of natural killer cells. Rev Bras Cancerol 54: 297-305, 2008.

37. Mariani E, Monaco MC, Cattini L, et al. Distribution and lytic activity of NK cell subsets in the elderly. Mech Ageing Dev 76:177-187, 1994.

\section{Correspondence}

Dr. Nilda SÜSLÜ

Hacettepe Üniversitesi Tıp Fakültesi

Kulak Burun Boğaz Anabilim Dalı

Sinhiye, ANKARA / TURKEY

Tel: (+90.312) 3051785

Fax: (+90.312) 3113500

e-mail: nildasuslu@yahoo.com 